\section{Biomarkers of outcome in rheumatoid arthritis}

\author{
Roberto Carrasco and Anne Barton \\ Arthritis Research UK, The University \\ of Manchester, Manchester, UK
}

\section{Introduction}

Rheumatoid arthritis (RA) is the most common autoimmune inflammatory arthritis, affecting approximately $1 \%$ of the population. This systemic disease is marked by chronic inflammation that predominantly affects the synovial membrane of diarthrodal joints. Its etiology is unknown, but it is presumed to be an immunological disease with contributing genetic $^{1}$ and environmental factors. ${ }^{2}$ Evidence suggests that RA develops in 3 phases: an asymptomatic period of genetic risk, a pre-clinical period in which RA-related antibodies can be detected, and a clinical phase with acute signs and symptoms of inflammatory arthritis. ${ }^{3}$

Evidence suggests that the sooner RA patients are treated, the better is their prognosis. ${ }^{4}$ The availability of markers that could help to identify patients with more aggressive, rapidly progressive RA with poorer prognosis would offer a rational basis for early and aggressive treatment. In that way it may be possible to avoid many irreversible clinical complications. ${ }^{5}$ The number of disease modifying anti-rheumatic drugs (DMARD) available has increased in recent years. The effectiveness, cost and toxicity of the new agents vary widely and the natural history of RA itself includes spontaneous remission, remission with medical treatment or continuously progressive disease despite medication. Hence, there is a clear need to identify efficient diagnostic and prognostic indicators of disease to assist clinicians and help them in making initial treatment choices.

This article is a literature review of current biomarkers to aid in the diagnosis of RA and emerging predictive markers of prognosis, but is non-systematic and therefore may be subject to publication and selection biases. No attempt has been made to assess the validity of studies or to compare risks between studies. Our aim was to review the literature in an inclusive manner.

\section{Markers of rheumatoid arthritis}

The intensive search for markers of prediction and prognosis in RA has been the subject of a large number of studies and a huge variety of possible markers have been reported, although not always validated. They can be classified in different groups or categories depending on their function and their location (Figure 1). A discussion of clinical and imaging biomarkers is beyond the scope of the current review, which will focus on biochemical markers.

\section{Biochemical markers}

For a long time, the diagnosis of RA was mainly based on clinical manifestations. However, it is often difficult to diagnose RA in the very early phases of the disease and in many cases irreversible damage had occurred by the time the diagnosis was confirmed. Therefore, laboratory tests which are sensitive and specific early in the disease course are desirable to allow earlier diagnosis and intervention. A multitude of such biomarkers have been investigated focusing on analytes found in the different cellular compartments including biomarkers involved in the synthesis and degradation of bone/cartilage, inflammation or autoimmune processes in order to identify those that could be clinically useful.

\section{Genetic markers}

Genetic markers in RA have been widely reviewed elsewhere. ${ }^{1}$ At least 12 genetic loci have been confidently identified as associated with susceptibility to RA but each locus confers a relatively modest effect and, even in combination, cannot be used to diagnose the condition as variants are common in the healthy population (Table 1). Only 2 show evidence of association with severity or outcome of disease. Firstly, variants within the human leukocyte antigen (HLA)-DRB1 gene show the strongest association with RA. ${ }^{6}$ In particular alleles encoding a shared amino acid motif are collectively called the shared epitope $(\mathrm{SE})^{7}$ and not only increase the risk of RA but are also associated with more severe disease. These alleles have been also reported to be associated with anti-citrullinated protein antibodies (ACPA) as measured by anti-cyclic citrullinated peptide (anti-CCP) antibodies. More severe disease with an increased rate of joint destruction has been found in patients with both antiCCP antibodies and SE alleles..$^{8-18}$ As anti-CCP antibodies are cheaper and easier to measure, testing for SE alleles carriage is not used clinically. Secondly, variants within the TRAF1/C5 susceptibility locus have been reported in two studies to be associated with erosive change independently of the SE. ${ }^{19,20}$ However, the risk conferred by carriage at the susceptibility variants is only in the order of 1.5 and so not clinically useful at the current time.

The peptidylarginine deiminase 4 (PADI4)
Correspondence: Dr Anne Barton, Arthritis Research UK Epidemiology Unit, Manchester Academic Health Sciences Centre, The University of Manchester, Stopford Building, Oxford Road, Manchester, M13, 9PT, UK.

E-mail: anne.barton@manchester.ac.uk

Key words: biomarkers, rheumatic diseases, rheumatoid arthritis.

Conflict of interest: the authors report no conflicts of interest.

Received for publication: 11 March 2010.

Revision received: 28 April 2010.

Accepted for publication: 19 May 2010.

This work is licensed under a Creative Commons Attribution 3.0 License (by-nc 3.0).

(C) Copyright R. Carrasco and A. Barton, 2010

Licensee PAGEPress, Italy

Rheumatology Reports 2010; 2:e3

doi:10.4081/rr.2010.e3

gene is of particular interest as it has been tested in Asian, European and North American populations and its relative effect in relation to RA susceptibility across these groups remains controversial. ${ }^{21-27}$ An interesting study suggests that the PADI4 genotype critically modulates the effect of anti-CCPs on clinical characteristics of RA and that the PADI4 genotype itself appears to influence joint destruction. ${ }^{24}$ However, in the largest study performed to date, the PADI4 genotype was not a significant risk factor for RA in people of European ancestry, in contrast to Asian populations. ${ }^{21}$ New studies are needed to clarify the role of PADI4 as RA marker.

In summary, HLA-DRB1 together with antiCCP antibodies remains the most reliable genetic marker for a more severe progress of RA. However, a number of new genetic loci are emerging and it is expected that some of them will also contribute to predict outcome in RA.

Although genetic markers have the advantage that they are stable over time, a number of serological markers have been investigated as diagnostic or prognostic aids in the management of RA. These are outlined below.

\section{Bone markers}

Receptor activator of nuclear factor $\kappa B$ ligand/osteoprotegerin

The receptor activator of nuclear factor $\kappa \mathrm{B}$ ligand (RANKL) is a member of the TNF superfamily; it is expressed on various cell populations and also exists as a soluble molecule. It is a key factor in the stimulation of osteoclast formation and activation. In turn, osteoclasts play a central role in the mechanism of joint destruction in RA. ${ }^{28}$ It has been demonstrated 
that $\mathrm{T}$ cells express RANKL and that there is overexpression of RANKL mRNA in the synovium of RA patients at the site of the bone resorption. ${ }^{29}$ The soluble receptor-like molecule osteoprotegerin (OPG), a decoy receptor, is a natural inhibitor of RANKL. Both RANKL and $\mathrm{OPG}$ can be measured in serum and the ratio RANKL/OPG is thought to regulate bone resorption. The COmbinatie therapie $\mathrm{Bij}$ Rheumatoide Artritis (COBRA) trial showed that a baseline value of a low ratio RANKL/OPG predicted a higher 5-year radiographic progression of joint damage. ${ }^{30}$ An independent study found that baseline levels of the RANKL:OPG-ratio in patients with early, active, untreated RA are strong independent predictors of rapid and persistent damage progression over 11 years follow up. ${ }^{31}$ Interestingly, another research group found that increased levels of OPG are effective in compensating for the action of soluble RANKL, but do not directly prevent bone degradation. ${ }^{32} \mathrm{~A}$ fourth study found that baseline levels of OPG and RANKL were not associated with radiographic progression at five or ten years. ${ }^{33}$ This discrepancy with the COBRA study might be related to differences in patient characteristics. Dysregulation of the RANK/RANKL/OPG system has been implicated in the pathophysiology of multiple bone remodeling disorders including osteoporosis, glucocorticoid-induced bone loss, multiple myeloma and rheumatoid arthritis. Therefore RANK/RANKL/OPG may eventually be used as markers of bone metabolism, though the broad role of RANKL signaling in the immune system may limit its specificity.

\section{Collagen cross-linked C-telopeptide of type I collagen}

Collagen cross-linked C-telopeptide (CTX-I) is a degradation product of C-terminal crosslinking telopeptide of type I collagen which has been suggested to be a candidate biomarker for joint destruction. A prospective study of patients with early RA showed that high baseline levels of urinary CTX-I predict increased risk of radiological progression and correlation with more rapid progression of joint destruction $^{34}$ whilst another long-term follow-up study noted correlation of serum CTX-I levels and subsequent joint destruction. ${ }^{33}$ These results suggest that CTX-I might be useful for identifying patients with a high risk of joint damage progression before damage can be detected radiographically.

\section{Bone sialoprotein}

Bone contains non-collagenous proteins such as bone sialoprotein (BSP) which is released during bone damage and can reflect the rate of bone turnover. ${ }^{35}$ Serum levels of bone sialoprotein were measured in the chronic and destructive arthritis induced in dark agouti (DA) rats after immunization with autologous rat native collagen type II in

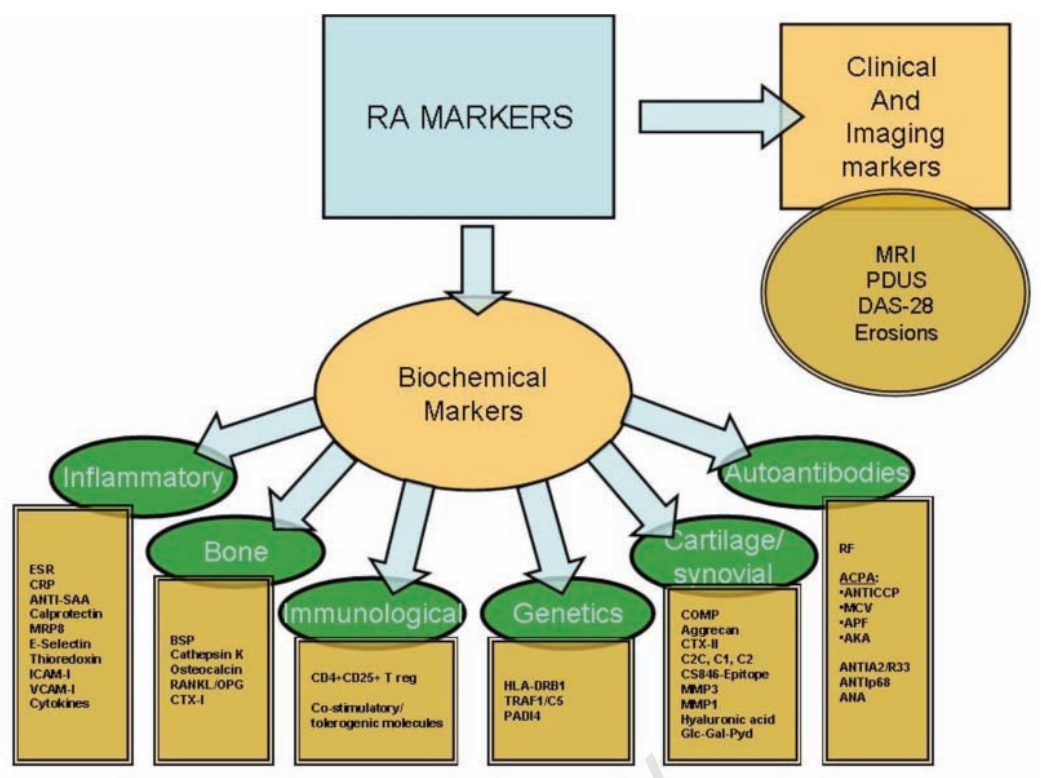

Figure 1. Classification schema for RA markers.

Table 1. Previously known rheumatoid arthritis risk associated SNPs in Europeans. Listed are the chromosome, SNP ID, and candidate gene(s) in the region. The table includes susceptibility loci with a $P_{\mathrm{GWAS}}<1 \times 10^{-5}$.

\begin{tabular}{|c|c|c|c|}
\hline Locus & ID & Gen & PGWAS \\
\hline lp36 & rs3890745 & TNFRSF14 & $3.6 \times 10^{-6}$ \\
\hline $1 p 13$ & rs2476601 & PTPN22 & $9.1 \times 10^{-74}$ \\
\hline $2 p 16$ & rs 13031237 & $R E L$ & $7.9 \times 10^{-7}$ \\
\hline $2 q 11$ & rs10865035 & AFF3 & $2.0 \times 10^{-6}$ \\
\hline $2 q 32$ & rs7574865 & STAT4 & $2.9 \times 10^{-7}$ \\
\hline $2 q 33$ & rs3087243 & CTLA4 & $1.2 \times 10^{-8}$ \\
\hline 6p21 & rs6910071 & $\begin{array}{l}H L A-D R B 1 \\
(* 0401 \text { tag) }\end{array}$ & $<10^{-299}$ \\
\hline $6 \mathrm{q} 23$ & rs6920220 & TNFAIP3 & $8.9 \times 10^{-13}$ \\
\hline $6 q 23$ & rs5029937 & TNFAIP3 & $7.5 \times 10^{-8}$ \\
\hline 9q33 & rs3761847 & TRAF1,C5 & $2.1 \times 10^{-7}$ \\
\hline 10p15 & rs4750316 & PRKCQ & $2.0 \times 10^{-6}$ \\
\hline $20 \mathrm{q} 13$ & rs4810485 & $C D 40$ & $2.8 \times 10^{-9}$ \\
\hline
\end{tabular}

Freund's incomplete adjuvant. Increased serum levels BSP were seen on day 21 after immunization and even higher levels were observed on day 28 at termination of the experiment, paralleling increases in the clinical joint score and histopathological signs of cartilage and bone erosions suggesting that it may be a marker of joint damage. ${ }^{36}$ In a study by Mansson et al. of 42 patients, BSP was quantified by enzyme linked immunosorbent (ELISA) assays in longitudinally collected knee joint synovial fluid (SF) samples of RA patients rapidly developing destruction in knees or hips, the "destructive" group $(\mathrm{n}=18)$, and in patients slowly developing destruction, the "non-destructive" group $(n=25)$. The destructive group was characterized by rising BSP concentrations in synovial fluid with time comparing with the initial levels $(\mathrm{P}<0.001){ }^{37}$ The authors conclude that this molecule contributes to the assessment of extent of tissue destruction and may help in the early identification of patients at risk of rapidly progressing destruction.

\section{Cathepsin K}

Cathepsin $\mathrm{K}$ is expressed by osteoclasts and synovial fibroblasts to degrade type I collagen during bone resorption and is hypothesized to play a role in the pathology of RA. ${ }^{38}$ Some studies suggest that it may be interesting as a marker of bone resorption..$^{39}$ For example, a study of 100 patients with active, longstanding RA found that the radiological destruction cor- 
related with the levels of cathepsin $\mathrm{K}^{32}$ However, this has not yet been validated so further studies will be required to investigate the role of cathepsin $\mathrm{K}$ as a marker of bone resorption in RA.

\section{Osteocalcin}

Osteocalcin is a large peptide that is synthesized by osteoclasts, odontoblasts and some chondrocytes. Circulating osteocalcin and its fragments reflect both bone formation and resorption..$^{40}$ In an experiment to study the changes in markers of bone metabolism, including osteocalcin, during anti-TNF treatment, it was found that the levels of osteocalcin were appreciably increased at 14 weeks compared with baseline, but not at 30 and 46 weeks, and no significant association was found between changes in disease activity and levels of osteocalcin at any of the time intervals. ${ }^{41}$ However, another study reported that osteocalcin fragments are released during osteoclastic bone resorption and that the quantification of specific age-modified osteocalcin fragments can provide an index of bone resorption suggesting that it may be a marker of joint erosion rather than disease activity. ${ }^{42}$

In summary, although many bone markers have been tested as potential biomarkers, the evidence, to date, suggests that the RANKL/OPG ratio is most reliable in predicting bone erosions. However, further larger studies are needed to confirm this and to assess the clinical utility.

\section{Synovial and cartilage markers}

\section{Cartilage oligomeric matrix protein}

Cartilage oligomeric matrix protein (COMP) is an extracellular matrix glycoprotein member of the thrombospondin family of calcium binding proteins. Several studies indicate that changes in COMP serum concentration are related to processes in cartilage. ${ }^{43}$ In a prospective study of 183 patients with early RA, it was found that early determination of serum COMP predicted the development of joint damage in the hands and feet by five years. ${ }^{44}$ Another study showed that changes in COMP levels appear to reflect the cartilage destruction process. ${ }^{45}$ In a longitudinal study of early RA in which serum concentration of COMP was measured in two well-defined patient groups with distinctly different disease outcomes it was reported that compared with a matched normal population, increased concentrations of COMP were found in all patients who developed rapid hip joint destruction. ${ }^{46}$ However, conflicting results were found in a number of other studies examining COMP as a predictor of joint damage..$^{33,47-49}$ The cause for the disparity between these results might be due to the fact that different COMP assays were used in these trials. In conclusion, serum COMP remains a strong candidate biomarker of RA and may be a valuable tool for identifying patients at high risk for rapid joint destruction but further studies are required to confirm this.

\section{Aggrecan/CS846-epitope}

Aggrecan is a major structural component of cartilage. It is cleaved by metalloproteinases to produce fragments that express neoepitopes due to the exposure of new terminal amino acid sequences. These fragments are found in normal, OA and RA cartilage and in synovial fluids.$^{50}$ Because aggrecan is one of the most abundant proteins of the cartilage matrix, current cartilage turnover markers are based mainly on immunological reagents detecting their synthesis and degradation. ${ }^{51}$ Aggrecan fragments are increased in the synovial fluid of RA patients ${ }^{38}$ and the levels have been related to disease severity. ${ }^{52}$ In one study, aggrecan was quantified by ELISA in longitudinally collected knee joint synovial fluid samples of both patients rapidly developing destruction in knee or hip joints and in patients slowly developing destruction and it was found that the aggrecan concentrations were initially highest in the group developing destruction $(\mathrm{P}<0.001) .{ }^{37}$ In a more recent study, it was found that levels of aggrecan fragments in human synovial fluid are increased in RA, 0A and after knee injury. ${ }^{53}$ Conversely, the data from a third study strongly suggests that total aggrecan levels are lower in RA patients than in healthy controls, and that RA patients have at least one specific subpopulation of aggrecan fragments, namely aggrecanse generated ${ }^{374} \mathrm{ARGSVI}$ fragments ${ }^{54}$ which, if confirmed, could help in differentiating RA from other types of arthritis.

The chondroitin sulphate epitope of aggrecan recognized by the monoclonal antibody 846 (CS846-epitope) is present in hardly detectable amounts in the normal adult cartilage. Preliminary in vitro studies indicate that the level of the epitope in cartilage is directly correlated with aggrecan biosynthesis. The available evidence suggests that fragments of aggrecan containing the 846 epitope reflect the degradation of newly synthesized aggrecan molecules. Serum concentration of CS846-epitope was measured in two patient groups with early RA but with distinctly different disease outcomes. ${ }^{46}$ The results showed that concentrations of CS846-epitope in patients with slow joint destruction were increased, whilst low levels were observed in patients with rapid joint destruction, concomitant with elevated levels of C-propeptide of type II procoliagen (CPII), suggesting a selective increase in collagen synthesis. Further clinical studies are needed to investigate the potential of aggrecan as a biochemical marker in destructive jointdiseases.

\section{C-terminal crosslinking telopeptide of type II collagen}

Urinary C-terminal crosslinking telopeptide of type II collagen (CTX-II) is a marker of cartilage destruction..$^{33}$ A prospective study of a cohort comprising 116 patients with early RA investigated the relationship between levels of urinary Glucosyl-Galactosyl-Pyridinoline (GlcGal-Pyd), urinary CTX-II and serum matrix metalloproteinase (MMP)-3 and the progression of joint destruction. The levels of Glc-GalPyd, CTX-II and MMP-3 were elevated compared with the levels in 76 healthy controls and high baseline levels of Glc-Gal-Pyd, CTX-II, and MMP-3 were associated with increased risk of progression of joint destruction over one year in early RA. ${ }^{55}$ Later, the same group investigated the relationship between baseline levels of urinary CTX-I and CTX-II and the mean annual progression of joint destruction over a median of four years and concluded that high baseline levels of urinary CTX-I and CTX-II independently predict an increased risk of radiological progression over four years in patients with early RA, especially those without radiological joint damage at onset. ${ }^{34}$ Another longitudinal analysis found that cartilage degradation as measured by urinary CTX-II and, to a lesser extent, bone degradation as measured by CTXI closely follow indices of RA activity. Clinically perceptible arthritis is responsible for immediate damage which will become visible on plain X-rays only much later. ${ }^{56}$ In experiments using experimental arthritis models (collageninduced arthritis (CIA) model and monoiodoacetate-induced arthritis (MIA) model) in rats, markedly increased levels of CTX-II were detected in the synovial fluid and the serum and both showed strong correlations with the microscopic severity scores of joint lesions at day 22 post-induction in the CIA model (synovial fluid CTX-II, $\mathrm{r}=0.76$; $\mathrm{P}<0.0001$; serum CTX-II $\mathrm{r}=0.85 ; \mathrm{P}<0.0001)$. In the MIA model, CTX-II concentration in the synovial fluid $(\mathrm{r}=0.53 ; \mathrm{P}<0.0001)$, but not in the serum, correlated with the microscopic severity score. ${ }^{57}$ In a recent prospective study of 66 RA patients and 76 healthy controls, in which measurements of urinary Glc-Gal-Pyd and CTX-II were performed at baseline and at one year, it was found that baseline levels of Glc-Gal-Pyd and CTX-II were increased in patients with RA and correlated with progression of joint damage..$^{58}$

Further support for CTX-II as a biomarker of joint progression was provided by a study of 148 RA patients receiving conventional DMARDs who participated in the SAMURAI trial. ${ }^{59}$ The 28 joint count disease activity score (DAS28), clinical improvement in signs and symptoms of RA, tender joint count, swollen joint count, and modified health assessment questionnaire (MHAQ) were assessed at baseline and 26 biological markers were measured. Among of a panel of 40 different variables, the investigators identified baseline joint damage, urinary CTX-II, the PYD/DPD (total pyridinoline /urinary total deoxypyridinoline) ratio and 
Body Mass Index (BMI) as strong and independent predictors of radiological progression in patients with RA receiving conventional DMARDs. Therefore, there are several lines of evidence to suggest that urinary CTX-II levels could be useful for detecting patients who are at high risk of joint damage progression very early in the disease before abnormalities can be detected radiographically.

\section{Matrix metalloproteinases}

In RA, degradation of articular cartilage is caused by proteinases derived from both the inflamed synovium and stimulated chondrocytes. In RA matrix metalloproteinase (MMP)$1{ }^{60}$ MMP- $3,{ }^{61}$ MMP-9 92 and membrane type 1 (MT1)-MMP ${ }^{63}$ are over-produced. These MMPs are secreted into the synovium and attack the cartilage immersed with synovial fluid. Interestingly, MMP-3 levels in rheumatoid synovial fluid are higher than other MMPs and in some studies have been shown to be predictive of joint destruction. ${ }^{64,65}$ For example, in a longitudinal study of 132 patients with early RA, levels of MMP-1, MMP-13, MMP-3, TIMP-1, and COMP were assessed in serially obtained serum samples. Levels of MMP-3, CTX-II, COMP and TIMP-1 correlated with radiographic progression at entry and longitudinally as assessed by area under the curve (AUC). By multivariate analysis, a model including MMP3 and CTX-II was identified as providing the best prediction of radiographic progression at baseline and a combination of MMP-3, CTX-II, and swollen joint count formed the best longitudinal AUC model. ${ }^{66}$ In another experiment involving patients with RA and systemic lupus erythematosus (SLE), it was found that levels of MMP-2 and MMP-9 were higher than controls in both groups of patients, supporting the involvement of MMP proteins in these autoimmune disorders. ${ }^{67}$ Baseline serum levels of 2 elements of the metalloproteinase network, MMP-1 and TIMP-1, reflected subsequent joint destruction.$^{68}$ All these data support the important potential role of MMP proteins as biomarkers in RA.

\section{Col2-3/4C long mono and Col2-3/4C $\mathrm{C}_{\text {short }}$}

Type II collagen (CII) is the main collagen of articular cartilage and is highly degraded in RA due to its cleavage by collagenases, exposing a neoepitope $\mathrm{Col} 2-3 / 4 \mathrm{C}_{\text {long mono }}$ (C2C), which can be detected by immunoassay. Two studies have found that $\mathrm{C} 2 \mathrm{C}$ as a measure of $\mathrm{CII}$ synthesis may be useful as a clinical prognostic biomarker for disease onset and activity in RA and as a predictor for joint space narrowing and radiographic damage progression. ${ }^{6970}$ By contrast, a third study showed no association between baseline serum levels of $\mathrm{C} 2 \mathrm{C}$ and radiographic progression. $^{33}$ A related neoepitope Col2$3 / 4 \mathrm{C}_{\text {short }}(\mathrm{C} 1,2 \mathrm{C})$ is a marker for degradation for type I collagen and type II collagen in cartilage ${ }^{69}$ and is related to specific joint space nar- rowing and erosion in RA. ${ }^{70}$ Thus, these biomarkers may be of value when studying progression of joint damage in RA patients but large, definitive studies are required.

\section{Glucosyl-Galactosyl-Pyridinoline}

Glucosyl-Galactosyl-Pyridinoline (Glc-GalPYD) is a recently described marker of synovial tissue (ST) destruction, which correlates with joint damage in RA. ${ }^{5,71}$ These findings were confirmed in a prospective study of 66 RA patients treated with infliximab and metotrexate. It was found that baseline urinary levels of Glc-Gal-PYD were elevated compared with the healthy controls and were associated with erosive changes. ${ }^{58}$ Measurement of this specific molecular marker may thus be useful in identifying patients with early RA at high risk of rapid progression of joint damage.

\section{Hyaluronic acid}

Soluble fragments of Hyaluronic Acid (HA) in sera of RA patients can be elevated from 10 to 20-fold compared with healthy controls and correlate with disease activity. ${ }^{72}$ However, HA levels vary significantly during the daytime and peak levels correspond to times of physical activity so the diagnostic utility of HA could be questioned. In a prospective study, 62 patients were followed for five years with radiographic examinations at baseline and at one, two and five years. It was found that HA at baseline correlated with the one, two and five year radiographic score. Interestingly, it was found that HA also correlated with other markers including ESR and CRP. ${ }^{47}$ An experiment including RA and OA patients showed that the highest concentration of HA was found in RA SF compared with asymptomatic donor and OA SF samples and that HA correlated with osteogenic protein 1 (OP-1) which, in turn, is correlated with cartilage degeneration. ${ }^{73}$

Of the synovial and cartilage markers, therefore, COMP, Aggrecan, CTX-II and MMPs show promise as possible biomarkers of rapidly progressive joint damage in RA patients. However, further studies are needed to confirm the associations and to determine whether a single or a combination of markers provides most accuracy in prediction.

\section{Autoantibodies}

\section{Rheumatoid factor}

Rheumatoid factor (RF) consists of antibodies directed against the Fc region of human IgG immunoglobulin. ${ }^{74}$ They are the hallmark of RA and can be detected in $60-80 \%$ of RA patients in hospital series. ${ }^{74} \mathrm{RF}$ was included in the 1987 laboratory criteria by the American Rheumatism Association (ARA). ${ }^{75}$ However, RF is not specific for RA and is found in other rheumatic diseases, other chronic inflammatory disorders, infections and even in healthy people. $^{76,77}$ The sensitivity for rheumatoid fac- tor in RA varies from $19-53 \%$ and the variation in specificity is from $91.7-98.6 \%{ }^{78} \mathrm{RF}$ is widely used for diagnosis and prognosis in RA and several studies have shown that it correlates with radiographic outcome. ${ }^{38,79,80}$ Its predictive value is dependent on the stage of the disease. ${ }^{76,81,82}$ Thus, in the early stages of RA, RF positivity is associated with more active disease and the development of erosions. However, in later phases of the disease, it is less predictive of subsequent joint progression. ${ }^{38,79}$ The RF assay is used as a marker for RA diagnosis, since its presence is associated with an increased risk of developing RA. ${ }^{83}$

Anti-critrullinated protein/peptide antibodies

Anti-critrullinated protein/peptide antibodies (ACPA) are antibodies to peptides or proteins containing citrulline, a modified form of the amino acid arginine. Several citrullinated antigens have been found.

\section{Antibodies against cyclic citrullinated peptide}

Perhaps even more predictive of disease progress in RA is the presence of antibodies against cyclic citrullinated peptide (anti-CCP). In recent years, several studies have demonstrated that the anti-CCP antibodies are predictive for RA and that they are associated with joint destruction. ${ }^{83-89}$ Anti-CCP can be detected years before RA onset and its specificity is higher than RF. ${ }^{8,84,85,87,89,90}$ Reported diagnostic sensitivities and specificities ranged from 39-94\% and $81-100 \%$, respectively. ${ }^{91}$ In 2007, anti-CCP antibodies were included in the European League Against Rheumatism (EULAR) guidelines for the diagnosis of early $\mathrm{RA}^{92}$ and in the American College Rheumatology (ACR) Criteria for RA classification. ${ }^{93}$ Anti-CCP positive RA shows a higher rate of local joint destruction and is associated with HLA-DRB1 alleles containing the shared epitope, while anti-CCP negative RA is associated with HLA-DR3. ${ }^{11,18,94 \cdot 97}$ The anti-CCP test also enables clinicians to distinguish RA patients from other arthritic diseases in cases where the RF is not useful since the anti-CCP test is highly specific for RA.

Antiperinuclear factor/antikeratin antibodies

Antiperinuclear factor (APF) and antikeratin antibodies (AKA) have been found to be as specific for RA as RF. ${ }^{98}$ The APF are present in $49-91 \%$ of RA patients with specificity from 7399\%. Antikeratin antibodies have been identified in the serum of RA patients with an estimated incidence of positive AKA reactions in RA sera from $36-59 \%{ }^{38}$ The presence of APF and AKA is independent of the disease duration. Both of them appear early and are sometimes present before the onset of RA. ${ }^{99,100}$ Thus, APF and AKA may help to identify RA to enable early intervention with treatment. These antibodies are correlated with each other, with the presence of RF and with the activity and severity of RA. ${ }^{101}$ Other studies have confirmed that 
measurement of anti-CCP, AKA, APF, and individual isotypes of RFs are useful for prediction of structural damage early in the disease course ${ }^{102}$ but it is not clear which is most useful. For example, it was reported that AKA and anti-CCP were similarly useful for diagnosing RA and were better than APF and the authors suggested that rheumatologists can choose either AKA or anti-CCP to test for and to help with the diagnosis of RA. ${ }^{103}$ The major issue is that the test for APF is difficult to perform and not routinely available.

\section{Anti-mutated citrullinated vimentin}

Mutated citrullinated vimentin (MCV) has been described as an important autoantigen expressed in synovial tissue and was formerly known as Sa. Anti-Sa antibodies have a high specificity for the diagnosis of RA (98\%) but a moderate sensitivity from $20-40 \%$. Anti-Sa also have a high predictive value for severe joint involvement and extraarticular disease in RA. ${ }^{104}$ Recently, a new ELISA test has been developed for anti-MCV testing, and can be used for the diagnosis of RA with similar specificity and sensitivity to anti-CCP antibodies..$^{105}$ In a two year follow-up study of 210 patients with early RA, antibodies against MCV, CCP type 2 and 3 (both of IgG isotype) and 3.1 (of both $\operatorname{IgG}$ and $\operatorname{IgA}$ isotype) were analyzed at baseline and disease activity was evaluated at baseline and regularly for 24 months. Radiographs of the hands and feet were graded using the Larsen score. This study showed that anti-MCV antibodies were associated with more severe disease, as measured by the DAS28, ESR and swollen joint count over time, compared with anti-CCP2, CCP3 and CCP3.1 tests. Interestingly, it was found that radiological progression was predicted equally by all 4 tests. ${ }^{106}$ In another study, where anti-MCV antibody levels were measured at baseline and at one year and two year follow up in 162 patients with early arthritis, it was found that anti-MCV had a specificity of $92.3 \%$ and a sensitivity of $59.3 \%$ when using the recommended cut-off of $20 \mathrm{U} / \mathrm{mL}$ and that anti-MCV-positive patients had a higher Sharp-van der Heijde score, ESR and CRP levels than did anti-MCV-negative patients at all time points. ${ }^{107}$ Recently, a number of publications have concluded that antiMCV antibodies are a specific and sensitive marker for the diagnosis of RA and could provide an alternative to anti-CCP testing. ${ }^{108-110}$

\section{Antip68}

Antibodies to stress protein immunoglobulin heavy-chain binding protein or chaperone (anti-BIP or antip68) are found in the sera of more than $60 \%$ of RA patients ${ }^{111}$ and are also found in experimental animal models of arthritis. ${ }^{11-113}$ Moreover, BIP is over-expressed in the rheumatoid joint and is present in early and pre-disease sera. ${ }^{114}$ These findings suggest that BIP may be an important autoantigen in
RA but its role as a potential biomarker has yet to be fully evaluated.

RF and anti-CCP antibodies are established biomarkers used in both diagnosis and prognosis of RA. Anti-MCV antibodies have been suggested as an alternative to anti-CCP antibody testing due to their high specificity and selectivity, similar or in some cases even higher than anti-CCP tests but it is not yet clear whether they are sufficiently superior to recommend routine testing in clinical practice.

\section{Inflammatory markers}

\section{Erythrocyte sedimentation rate}

A number of studies have suggested that high erythrocyte sedimentation rate (ESR) levels at onset of early RA predicts long-term radiological progression. ${ }^{92,115}$ It is, together with CRP, the most frequently used laboratory measure reflecting disease activity. ESR measurements tend to reflect disease activity of the previous weeks ${ }^{116}$ and has been incorporated in several disease activity scoring systems, but its measurements are influenced by confounding factors including age, sex, fibrinogen levels, RF, hypergammaglobulinemia, and anemia. ${ }^{117}$ Nonetheless, the ESR level has been incorporated into a risk prediction model for rapid radiographic progression (RRP) that in the future could be used to predict the risk of joint damage progression in RA patients. ${ }^{118}$

\section{C-reactive protein}

Human C-reactive protein (CRP) is one of the most responsive acute-phase serum reactants and its levels in patients with RA has been correlated with clinical disease activity, radiological progression and response to therapy. ${ }^{38,116,119}$ As with ESR, CRP has been incorporated into several disease activity scoring systems, but CRP is considered to be more specific biomarker for RA disease activity than ESR, since the hepatic production of CRP reflects the effects of inflammatory cytokines in the liver. ${ }^{120}$ Interestingly, CRP reflects more shortterm changes in disease activity compared with ESR. ${ }^{116}$ The serum levels of CRP not only reflect the extent of disease activity but are also associated with joint destruction. ${ }^{66,121}$ In an inception cohort of patients with early inflammatory polyarthritis followed prospectively for outcome, CRP was found to be the best predictor of radiographic damage by five years. ${ }^{122}$ In addition, CRP determination is widely available, easy to perform and of low cost, making it the preferred biomarker of disease activity.

\section{Calprotectin}

Calprotectin is a major leukocyte protein that has been shown to correlate with laboratory and clinical assessments in inflammatory diseases. ${ }^{123}$ High levels of calprotectin have been reported in SF of patients with $\mathrm{RA}^{124}$ and one study found it to be highly significantly correlated with joint damage measures in addition to laboratory and clinical markers of inflammation. ${ }^{125}$ This has been supported by the findings of a recent study in which calprotectin was an independent predictor of clinical and radiographic joint damage after ten years, suggesting that calprotectin may be a prognostic biomarker for erosive disease in patients with RA. ${ }^{126}$

\section{Serum amyloid-associated protein}

Serum amyloid-associated protein (SAA) is a precursor for Amyolid A and, similar to CRP, correlates with several clinical parameters in inflammatory disease ${ }^{127}$ but SAA levels are generally higher and vary more among individuals. ${ }^{128}$ One study reported that SAA is an inducer of MMPs in the synovial tissue fibroblasts of RA patients. ${ }^{129}$ Therefore, SAA may play a significant role in the degradation of extracellular matrix in joint tissues of RA patients. However, SAA measurements correlate significantly with CRP levels in sera of patients with RA, but not in healthy subjects suggesting that they do not provide additional information. ${ }^{129}$ More recently, another study showed that the incorporation of SAA together with anti-CCP in a RA diagnosis model, increased the sensitivity compared with the anti-CCP alone, but decreased the selectivity of the model..$^{86}$

Others markers of inflammation such as ESelectin, ${ }^{130,131}$ Thioredoxin, ${ }^{132,133}$ intracellular adhesion molecule (I-CAM) $1^{130,134-136}$ and vascular cell adhesion molecule (V-CAM) $1^{130,135,137}$ have been found to correlate with disease activity in RA but there is little evidence to suggest that additional information is gained over and above measurement of ESR and CRP. Thus, ESR and CRP remain the two biomarkers used routinely in clinical practice.

\section{Cytokines/inhibitors/adipocytokines}

In RA, the balance between pro- and antiinflammatory cytokines is tilted toward continued inflammation. The normally low levels of pro-inflammatory cytokines become chronically increased causing prolonged inflammation. Therefore, inappropriate activity of the main inflammatory cytokines and their receptors could potentially have an important role in the RA pathogenesis. A broad array of macrophage and fibroblast cytokines, including interleukin (IL) -1, IL-6, IL-15, IL-18, tumor necrosis factor (TNF)- $\alpha$, granulocyte macrophage-colony stimulatory factor (GM-CSF), various chemokines and many others are produced by the rheumatoid synovium. ${ }^{138}$ Many of them, such as IL- $1 \alpha$ and $\beta$, IL-6, M-CSF, IL-15, IL-17 and TNF- $\alpha$, enhance osteoclast formation, activity and survival. ${ }^{139-141}$ Pro-inflammatory cytokines such as IL-6, TNF- $\alpha$ and IL-1 are present at higher levels in the SF of RA patients compared with other arthritic disorders or normal patients. Levels of both TNF- $\alpha$ and IL- 6 are elevated in serum and joints during active RA and 
Table 2. Biomarkers of outcome in rheumatoid arthritis.

$\begin{array}{lll}\text { Biomarker Source Putcome Physiological function } & \text { Ref. } \\ \text { Auto-antibodies } & \end{array}$

RF Blood Severity and radiological progression

Autoantibody against the Fc portion of IgG. RF

$74,76,80-83$

\begin{tabular}{lcl} 
AKA; AFA; APF & Blood & RA development \\
& & \\
& Blood & Development and severity of RA \\
\hline Anti-CCP & Blood & Disease activity and radiological p \\
MCV & Blood & $\begin{array}{l}\text { Disease activity and progression } \\
\text { of radiological damage }\end{array}$ \\
\hline Inflammatory markers &
\end{tabular}
contribute to the disease.

AKA label the stratum corneum of various cornified epithelia; APF label the keratohyalin granules of human $99-103$ buccal mucosa epithelium; AFA are autoantibodies to filaggrins, an important class of the intermediate filament-associated proteins which interact with

keratin intermediate filaments. proteins during inflammation. Antibodies against mutated citrullinated vimentin.

\begin{tabular}{lll} 
A-SAA & $\begin{array}{l}\text { Blood and } \\
\text { synovial tissue }\end{array}$ & $\begin{array}{l}\text { Disease activity and cartilage } \\
\text { degradation }\end{array}$ \\
& & \\
\hline $\begin{array}{l}\text { Cytokineslinhibitors } \\
\text { (e.g., TNF- } \alpha, \text { IL-1, }\end{array}$ & $\begin{array}{l}\text { Blood and } \\
\text { synovial fluid }\end{array}$ & $\begin{array}{l}\text { Disease activity, } \\
\text { inflammation, therapeutic response }\end{array}$ \\
IL-6, IL-8, IL-16) & and membrane & and radiographic progression
\end{tabular}

Acute-phase reactants; CRP binds to phosphocholine on microbes, to assist in complement binding to foreign $38,115,116,118-121$ and damaged cells and enhances phagocytosis by macrophages. Innate immunity.
$\begin{array}{ll}\text { Transport of cholesterol, } & \text { 127,128 }\end{array}$
recruitment of immune cells to inflammatory sites, and the induction of enzymes that degrade extracellular matrix.

T-cell differentiation, expansion and survival,

NK-cell activation, T-cell and NK-cell cytotoxicity,

B-cell activation and proliferation,

Th1-cell proliferation and maturation, Th17-cell expansion and stabilization. T-cell chemokinesis and memory maintenance, synovial fibroblast activation, macrophage activation/suppression, adhesion molecule expression and oxidative burst. Increase of macrophage cytokine release, T-cell cytokine release and hepatic acute-phase response. Growth and differentiation of mesenchymal, epithelial and neuroectodermal cells. Angiogenesis. Cytokines, chemokines, MMP, iNOS and $\mathrm{PG}$ release. Antibody-mediated immunity. Control of parasitic infections. Cell-mediated immunity

\begin{tabular}{|c|c|c|c|c|}
\hline Calprotectin & $\begin{array}{l}\text { Blood } \\
\text { and synovial } \\
\text { fluid }\end{array}$ & Inflammation and radiographic damage & $\begin{array}{l}\text { Calcium and zinc binding protein; bacteriostatic and fungistatic } \\
\text { immunomodulating and antiproliferative effects; } \\
\text { chemotactic factor for neutrophils. }\end{array}$ & $123-126$ \\
\hline E-selectin & Blood & Severity and disease activity & Recruitment of leukocytes; leukocyte adhesion to the & 130,131 \\
\hline
\end{tabular}

\begin{tabular}{|c|c|c|c|}
\hline E-selectin & Severity and disease activity & $\begin{array}{l}\text { Recruitment of leukocytes; leukocyte adhesion to the } \\
\text { wall of the vascular endothelium }\end{array}$ & 130,131 \\
\hline sVCAM, ICAM & Cardiovascular risk & $\begin{array}{l}\text { VCAM1: adhesion of lymphocytes, monocytes, eosinophils, } \\
\text { and basophils to vascular endothelium; leukocyte-endothelial } \\
\text { cell signal transduction. ICAM1: stabilizing cell-cell interactions } \\
\text { and facilitating leukocyte endothelial transmigration. }\end{array}$ & $130,135,136$ \\
\hline Thioredoxin & Blood Disease activity & $\begin{array}{l}\text { Antioxidant by facilitating the reduction of other proteins } \\
\text { by cysteine thiol-disulfide exchange. }\end{array}$ & 132,133 \\
\hline
\end{tabular}

\begin{tabular}{|c|c|c|c|c|}
\hline \multicolumn{5}{|c|}{ Synovium/cartilage markers } \\
\hline Hyaluronic acid & Blood & $\begin{array}{l}\text { Activity and duration of disease. } \\
\text { Erosive status }\end{array}$ & $\begin{array}{l}\text { Contributes to tissue hydrodynamics, movement and } \\
\text { proliferation of cells,and participates in a number of cell } \\
\text { surface receptor interactions. }\end{array}$ & 47,72 \\
\hline COMP & Blood & Radiographic progression, disease severity. & $\begin{array}{l}\text { Involved in cell adhesion, platelet aggregation, cell } \\
\text { proliferation, angiogenesis, tumor metastasis, and tissue repair. }\end{array}$ & $36-38,43-47$ \\
\hline $\begin{array}{l}\text { Aggrecan/ } \\
\text { CS846-epitope }\end{array}$ & Blood & Cartilage erosion/joint damage & $\begin{array}{l}\text { Aggrecan mediates chondrocyte-chondrocyte and } \\
\text { chondrocyte-matrix interactions } \\
\text { through its ability to bind hyaluronan; Cell adhesion; } \\
\text { chondrocyte apoptosis; cartilage structure. }\end{array}$ & $37,38,46,51-54$ \\
\hline Glc-Gal-PYD & Urine & Progression of joint damage & Cartilage structure. & 55,58 \\
\hline CTX-II & Urine & $\begin{array}{l}\text { Cartilage destruction and radiographic } \\
\text { progression }\end{array}$ & Cartilage structure. & $33,34,55-58,70$ \\
\hline MMPs & Blood & Radiographic progression and disease activ & Cleave extracellular matrix proteins; cartilage destruction. & $60,61,65,66,68$ \\
\hline $\mathrm{C} 2 \mathrm{C} ; \mathrm{Cl}, 2 \mathrm{C}$ & Blood & Radiographic damage & Cartilage structure. & 33,70 \\
\hline
\end{tabular}


Table 2. Continued from previous page.

\begin{tabular}{|c|c|c|c|c|}
\hline \multicolumn{5}{|l|}{ Bone markers } \\
\hline Osteocalcin & Blood & Bone mineral density and RA activity & $\begin{array}{l}\text { Osteoblast differentiation; bone mineralization } \\
\text { and calcium ion homeostasis. }\end{array}$ & $40-42$ \\
\hline Cathepsin K & $\begin{array}{l}\text { Blood and } \\
\text { synovial fluid }\end{array}$ & Bone destruction & Bone remodeling and resorption & $32,38,39$ \\
\hline BSP & $\begin{array}{l}\text { Blood and } \\
\text { synovial fluid }\end{array}$ & Bone destruction & $\begin{array}{l}\text { Properties of a nucleator, associated with mineral } \\
\text { crystal formation; angiogenesis; protection from } \\
\text { complement-mediated cell lysis. }\end{array}$ & $35,37,46$ \\
\hline CTX-I & Urine and blood & $\begin{array}{l}\text { Bone destruction and } \\
\text { radiographic } \\
\text { progression }\end{array}$ & Bone structure. & 33,34 \\
\hline RANKL and $\mathrm{OPG}$ ratio & $\begin{array}{l}\text { Blood and } \\
\text { synovial fluid }\end{array}$ & Bone destruction & $\begin{array}{l}\text { RANKL is involved in stimulation of osteoclast formation and activation; } \\
\text { OPG inhibits the differentiation of osteoclast precursors into } \\
\text { osteoclasts and also regulates the resorption of osteoclasts. }\end{array}$ & $28-30,32$ \\
\hline \multicolumn{5}{|c|}{ Immunological markers } \\
\hline Regulatory T cells & $\begin{array}{l}\text { Blood and } \\
\text { synovial fluid }\end{array}$ & Disease development and activity & $\begin{array}{l}\text { Suppress activation of the immune system and prevent } \\
\text { pathological self-reactivity. }\end{array}$ & $157,162,163,165-167$ \\
\hline $\begin{array}{l}\text { Cytokines/lnhibitors } \\
\text { (e.g. IL-1, IL-6, } \\
\text { IL-8, IL-16) }\end{array}$ & $\begin{array}{l}\text { Blood and } \\
\text { synovial fluid } \\
\text { and membrane }\end{array}$ & $\begin{array}{l}\text { Disease activity, inflammation, } \\
\text { therapeutic response and } \\
\text { radiographic progression }\end{array}$ & $\begin{array}{l}\text { T-cell differentiation, expansion and survival, } \\
\text { NK-cell activation, T-cell and NK-cell cytotoxicity, } \\
\text { B-cell activation and proliferation, Thl-cell proliferation } \\
\text { and maturation, Th17-cell expansion and stabilization. } \\
\text { T-cell chemokinesis and memory maintenance, synovial fibroblast } \\
\text { activation, macrophage activation/suppression, adhesion molecule } \\
\text { expression and oxidative burst. Increase of macrophage cytokine } \\
\text { release, T-cell cytokine release and hepatic acute-phase response. } \\
\text { Growth and differentiation of mesenchymal, epithelial and } \\
\text { neuroectodermal cells. Angiogenesis. Cytokines, chemokines, } \\
\text { MMP, iNOS and PG release. Antibody-mediated immunity. } \\
\text { Control of parasitic infections. Cell-mediated immunity }\end{array}$ & $86,138-150 ; 153-156$ \\
\hline
\end{tabular}

RF: rheumatoid factor; AKA: antikeratin antibodies; AFA: antifilaggrin antibodies; APF: antiperinuclear factor; MCV: antimutated citrullinated vimentin; CRP: C-reactive protein/ ESR: erythrocyte sedimentation rate; A-SAA: acute serum amyeloid protein; COMP: cartilage oligomeric protein; Glc-Gal-PYD: urinary glucosyl-galactosyl-pyridinoline; CTX-II: C-terminal crosslinking telopeptide type II; MMPs: matrix metalloproteases; BSP: bone sialoprotein; CTX-I: C-terminal crosslinking telopeptide type I; RANKL: receptor activator for nuclear factor B ligand; OPG: osteoprotegerin.

Table 3. Biomarkers in rheumatoid arthritis vs. other diseases.

\begin{tabular}{|c|c|c|}
\hline Biomarker in RA & Other diseases & Ref. \\
\hline \multicolumn{3}{|l|}{ Autoantibodies } \\
\hline $\mathrm{RF}$ & Sjogren's syndrome, crioglobulinemia, SLE & $76,77,81,83$ \\
\hline AKA, AFA, APF & $\operatorname{ReA} \rightleftharpoons-2$ & 100 \\
\hline Anti-CCP & AS, ReA, PsA, SLE, CREST, systemic sclerosis, Sjogren’s syndrome & $18,82,83,86,90,93,94$ \\
\hline MCV & $\begin{array}{l}\text { OA, UA, PSA, SLE, Sjogren's syndrome, scleroderma, AS, systemic sclerosis, } \\
\text { viral hepatitis B, tuberculosis, PMR }\end{array}$ & $107-110$ \\
\hline \multicolumn{3}{|l|}{ Inflammatory markers } \\
\hline $\begin{array}{l}\text { Cytokineslinhibitors } \\
\text { (e.g., TNF- } \alpha \text {, IL-1, IL-6, IL-8, IL-16) }\end{array}$ & OA, GOUT, PMR, ReA, acute crystal arthritis & $141-143,150$ \\
\hline Calprotectin & $\mathrm{OA}$ & 123,124 \\
\hline E-selectin & $\mathrm{OA}$ & 130,137 \\
\hline sVCAM, ICAM & OA, IA, SLE & $130,134,135,137$ \\
\hline Thioredoxin & OA, GOUT, ReA & 133 \\
\hline \multicolumn{3}{|l|}{ Synovium/cartilage markers } \\
\hline Hyaluronic acid & $\mathrm{OA}$ & 73 \\
\hline COMP & $\begin{array}{l}\text { JCA, OA, SLE, ReA, PsA, Scleroderma, vasculitis, Sjogren’s syndrome, } \\
\text { Raynaud's syndrome }\end{array}$ & 43,49 \\
\hline Aggrecan/ CS846-epitope & $\mathrm{OA}$ & 50 \\
\hline Glc-Gal-PYD & Paget's disease & 71 \\
\hline MMPs & IA, OA, SLE & $62,64,67$ \\
\hline $\mathrm{C} 2 \mathrm{C}, \mathrm{C} 1,2 \mathrm{C}$ & $\mathrm{AO}, \mathrm{PsA}$ & 69 \\
\hline \multicolumn{3}{|l|}{ Bone markers } \\
\hline BSP & PsA & 35 \\
\hline \multicolumn{3}{|l|}{ Immunological markers } \\
\hline Regulatory T cells & PsA, JIA, spondyloarthropathies, ReA & 162,165 \\
\hline
\end{tabular}

RF: rheumatoid factor; AKA: antikeratin antibodies; AFA: antifilaggrin antibodies; APF: antiperinuclear factor; MCV: antimutated citrullinated vimentin; COMP: cartilage oligomeric protein; Glc-Gal-PYD: urinary glucosylgalactosyl-pyridinoline; MMPs: matrix metalloproteases; BSP: bone sialoprotein; SLE: systemic lupus erythematosus; ReA: reactive arthritis; AS: ankylosing spondylitis; PsA: psoriatic arthritis; OA: osteoarthritis; UA: undifferentiated arthritis; PMR: polymyalgia rheumatica; IA: inflammatory arthritis; JCA: juvenile chronic arthritis; JIA: juvenile idiopathic arthritis. 
are thought to contribute to the joint destruction in RA. ${ }^{140,142,143}$ IL- 6 is the most abundant cytokine in the serum and SF of patients with RA and its levels have been shown to correlate with disease activity in both fluids. However, reports are conflicting about whether IL-6 levels correlate with joint destruction with some suggesting they $\mathrm{do}^{144}$ but others showing no association with progression. ${ }^{145,146}$ Moreover, baseline IL- 6 concentrations may vary almost 100 -fold between different individuals, can increase with exercise ${ }^{147}$ and are elevated in several other diseases characterized by inflammation. In a multivariate analysis of biomarkers in RA, it was found that the combination of anti-CCP with IL-6 had the greatest discrimination for the diagnosis of established $\mathrm{RA}^{86}$ but whether it is a useful biomarker for outcome remains questionable.

Soluble TNF receptor (sTNFR)-II parallels TNF- $\alpha$ levels and is a surrogate marker for inflammation. One study suggested that levels of sTNFRII can be elevated up to 12 years prior to the development of RA and so it may be a potential biomarker of future disease development. ${ }^{148}$ Similarly, in an extensive analysis of 16 cytokines or cytokine-related markers, 7 of the analytes (IL-1 $\alpha$, IL-1 $\beta$, IL1-receptor antagonist (Ra), IL-4, IL-10, TNF- $\alpha$ and sTNFRI) were found to be significantly elevated at five years before the diagnosis of RA. ${ }^{149}$ In another study, a panel of 23 cytokines and chemokines was measured in SF from patients with early synovitis, who where subsequently followed up. It was reported that patients who develop RA had a distinct but transient SF cytokine profile. The levels of cytokines such as IL-2, IL-4, IL-13, IL-17, IL-15, basic fibroblast growth factor (bFGF) and endothelial growth factor (EGF), were significantly elevated in these patients three months after symptom onset, when compared with early arthritis patients who did not develop RA. ${ }^{150}$ In addition, this profile was no longer present in established RA. Other cytokines such as IL-4, interferon (IFN)$\gamma$, IL-13 and IL-18 inhibit osteoclastogenesis, whereas suppressive cytokines like transforming growth factor (TGF)- $\beta$ and IL-1Ra, as well as the suppressor of cytokines signaling-3 (SOCS3), are expressed in RA synovium but at levels that are inadequate to block synovitis. ${ }^{138}$

Production of IL-17 is now believed to play a crucial role in the development of joint lesions in RA as IL-17 can induce the production of pro-inflammatory cytokines (IL-1 and TNF- $\alpha$ ), the upregulation of RANKL and stimulate the activity of MMPs, matrix catabolism and bone resorption. ${ }^{151,152}$ In RA patients, high local levels of IL-17A are present in both synovium and synovial fluid..$^{141}$ Furthermore, a recent clinical study demonstrated that synovial IL-17A expression is associated with joint destruction. ${ }^{153}$ Adipocytokines are produced in adipose tissue and modulate inflammatory responses and radiographic joint damage. In a recent study, concentrations of adipocytokines such as, leptin, visfatin, resistin and adiponectin were measured in RA patients and healthy controls. ${ }^{154}$ It was found that concentrations of adipocytokines are elevated in patients with RA and may modulate radiographic joint damage. For example, visfatin was associated with increased, and leptin with reduced, levels of radiographic joint damage.

ST and SF from RA patients contain elevated concentrations of several chemokines such as monocyte chemo-attractant protein (MCP)-1, macrophage inflammatory protein (MIP) $1 \alpha$, RANTES, MCP-4, pulmonary and activationrelated chemokine (PARC), MIP-3 $\alpha$, growthrelated oncogene (GR0), IL-8, monocyte induced by IFN- $\gamma$ (Mig), interferon- $\gamma$-inducible protein (IP)-10 and stromal cell-derived factor (SDF)-1. ${ }^{155}$ A recent study found that some of these chemokines (MIP-3, transforming growth factor (TGF), CXCL13, monocyte colony stimulating factor (M-CSF)) were predictive of RA disease activity. ${ }^{156}$ These chemokines are involved in RA pathogenesis via the recruitment and retention of leukocytes in the joints. However, a number of chemokines have been shown to have other biological functions, such as release of mediators of inflammation, cell proliferation and angiogenesis. Therefore, cytokines and cytokine-related molecules are key molecules in the pathogenesis of RA. Further prospective studies are needed to understand their role in the disease and their possible use as biomarkers in RA.

The traditional markers, ESR and CRP, remain the most reliable inflammatory markers in the clinical setting. Due to the complexity of the cytokine network and the instability of these cytokine markers it is not clear whether they can be used in a clinical setting as biomarkers. However, further studies including families of cytokines, chemokines and adipocitokines are necessary to assess the value of more complex models as predictors of outcome in RA.

\section{Immunological markers}

In RA, the prominent T-cell infiltrate suggests that the rheumatoid synovium contains large number of $\mathrm{CD}^{+} \mathrm{T}$ cells. An accepted model is that the chronic inflammation in established RA is mainly driven by interactions between $\mathrm{T}$ cells, macrophages and fibroblasts in an abnormal environment. ${ }^{157}$ Several types of Treg cells have been described. Thymicallyderived $\mathrm{CD} 4{ }^{+} \mathrm{CD} 25^{+}$Treg cells play a role in the maintenance of self tolerance and prevention of autoimmune disease. ${ }^{158}$ Treg cells can be divided into subpopulations such as T helper 3 (Th3) cells, which play an important role in mediating tolerance. ${ }^{159}$ These cells might be insufficiently effective or even defective in RA. ${ }^{160,161}$ A number of studies have reported that
$\mathrm{CD}^{+} \mathrm{CD} 25^{+}$Tregs are increased in the inflamed joint and present a more powerful suppressor activity than peripheral $\mathrm{CD} 4^{+} \mathrm{CD} 25^{+}$ Tregs. ${ }^{162-164}$ However, RA is not suppressed despite this increased suppressor activity. The opinion from the authors is that the effector cells might be less sensitive for the suppression of $\mathrm{CD} 4{ }^{+} \mathrm{CD} 25^{+}$Tregs. Several studies have compared $\mathrm{CD} 4{ }^{+} \mathrm{CD} 25^{+}$Tregs in patients with RA and other types of inflammatory arthritis $^{162,163,165-167}$ and a number have reported an enrichment of $\mathrm{CD}^{+}{ }^{+} \mathrm{CD} 25^{+}$Tregs in SF of patients with RA and other types of inflammatory arthritis. This enrichment is independent of disease duration and severity. In addition SF $\mathrm{CD} 4^{+} \mathrm{CD} 25^{+}$Tregs showed suppressive activity in terms of cytokine production and proliferation. The role of Tregs as potential biomarkers of disease state or outcome remains controversial, however, as different studies have reported similar, ${ }^{166,167}$ increased ${ }^{163}$ or decreased ${ }^{162,165}$ frequencies of $\mathrm{CD}^{+} \mathrm{CD} 25^{+}$Tregs in SF when compared to normal controls.

\section{Conclusions}

During recent years, a huge number of potential biomarkers of prognosis (Table 2) and diagnosis (Table 3) in RA have been investigated but only the autoantibody tests (RF and anti-CCP) and inflammatory markers (ESR and CRP) are currently tested routinely in clinical practice. The best marker for the development of erosions remains the anti-CCP2 antibody test but this lacks sensitivity in early disease. Correlation of outcome with other biomarkers, including CTX-I, CTX-II, COMP, GlcGal-Pyd, MMP3 and C2C in urine or serum samples have been reported in more than one study or patient group (Table 2). Whether these markers correlate with each other or add any information over and above that provided by autoantibodies and inflammatory markers is not known but it would seem reasonable to investigate these as a panel of biomarkers may provide more information than the single testing largely attempted to date.

The prospective cohort studies provide an opportunity to find new and better biomarkers, improving prognosis and diagnosis of the disease, making it possible to distinguish patients who will develop more aggressive or rapidly progressive disease from the patients who will develop a milder disease who could be spared potentially toxic medications. Prospective cohort studies also permit the study of the effects of different therapies throughout time and to assess the evolution of the disease in each case. New complex models involving several biomarkers and clinical markers may result in a biomarker signature capable of predicting and monitoring a variety of outcomes 
important to patients. In turn, this has the potential to allow tailoring of treatment regimens to groups of patients according to their biomarker signature and would truly represent personalized medicine.

\section{References}

1. Barton A, Worthington J. Genetic susceptibility to rheumatoid arthritis: an emerging picture. Arthritis Rheum 2009;61:1441-6

2. Symmons D, Harrison B. Early inflammatory polyarthritis: results from the Norfolk arthritis register with a review of the literature. I. Risk factors for the development of inflammatory polyarthritis and rheumatoid arthritis. Rheumatology (Oxford) 2000;39:835-43.

3. Majka DS, Holers VM. Can we accurately predict the development of rheumatoid arthritis in the preclinical phase? Arthritis Rheum 2003;48:2701-5.

4. Landewé RB. The benefits of early treatment in rheumatoid arthritis: confounding by indication, and the issue of timing. Arthritis Rheum 2003;48:1-5.

5. Lard LR, Visser H, Speyer I, et al. Early versus delayed treatment in patients with recent-onset rheumatoid arthritis: comparison of two cohorts who received different treatment strategies. Am J Med 2001;111:446-51.

6. Wellcome Trust Case Control Consortium. Genome-wide association study of 14,000 cases of seven common diseases and 3,000 shared controls. Nature 2007;447:661-78.

7. Gregersen PK, Silver J, Winchester RJ. The shared epitope hypothesis. An approach to understanding the molecular genetics of susceptibility to rheumatoid arthritis. Arthritis Rheum 1987;30:120513.

8. Berglin E, Padyukov L, Sundin U, et al. A combination of autoantibodies to cyclic citrullinated peptide (CCP) and HLADRB1 locus antigens is strongly associated with future onset of rheumatoid arthritis. Arthritis Res Ther 2004;6:R303-8.

9. Furuya T, Hakoda M, Ichikawa N, et al. Differential association of HLA-DRB1 alleles in Japanese patients with early rheumatoid arthritis in relationship to autoantibodies to cyclic citrullinated peptide. Clin Exp Rheumatol 2007;25:219-24.

10. Huizinga TW, Amos CI, van der Helm-van Mil AH, et al. Refining the complex rheumatoid arthritis phenotype based on specificity of the HLA-DRB1 shared epitope for antibodies to citrullinated proteins. Arthritis Rheum 2005;52:3433-8.
11. Irigoyen $\mathrm{P}$, Lee AT, Wener $\mathrm{MH}$, et al. Regulation of anti-cyclic citrullinated peptide antibodies in rheumatoid arthritis: contrasting effects of HLA-DR3 and the shared epitope alleles. Arthritis Rheum 2005;52:3813-8.

12. Kaltenhäuser $S$, Pierer $M$, Arnold $S$, et al. Antibodies against cyclic citrullinated peptide are associated with the DRB1 shared epitope and predict joint erosion in rheumatoid arthritis. Rheumatology (Oxford) 2007;46:100-4.

13. Orozco G, Pascual-Salcedo D, Lopez-Nevot MA, et al. Auto-antibodies, HLA and PTPN22: susceptibility markers for rheumatoid arthritis. Rheumatology (Oxford) 2008;47:138-41.

14. Reneses S, Gonzalez-Escribano MF, Fernandez-Suarez A, et al. The value of HLA-DRB1 shared epitope, -308 tumor necrosis factor-alpha gene promoter polymorphism, rheumatoid factor, anti-citrullinated peptide antibodies, and early erosions for predicting radiological outcome in recent-onset rheumatoid arthritis. J Rheumatol 2009;36:1143-9.

15. Shadick NA, Heller JE, Weinblatt ME, et al. Opposing effects of the D70 mutation and the shared epitope in HLA-DR4 on disease activity and certain disease phenotypes in rheumatoid arthritis. Ann Rheum Dis 2007;66:1497-502.

16. van der Helm-van Mil AH, Verpoort KN, Breedveld FC, et al. The HLA-DRB1 shared epitope alleles are primarily a risk factor for anti-cyclic citrullinated peptide antibodies and are not an independent risk factor for development of rheumatoid arthritis. Arthritis Rheum 2006;54:111721.

17. van Gaalen FA, van Aken J, Huizinga TW, et al. Association between HLA class II genes and autoantibodies to cyclic citrullinated peptides (CCPs) influences the severity of rheumatoid arthritis. Arthritis Rheum 2004;50:2113-21.

18. Verpoort KN, van Gaalen FA, van der Helm-van Mil AH, et al. Association of HLA-DR3 with anti-cyclic citrullinated peptide antibody-negative rheumatoid arthritis. Arthritis Rheum 2005;52:305862.

19. Kurreeman FA, Padyukov L, Marques RB, et al. A candidate gene approach identifies the TRAF1/C5 region as a risk factor for rheumatoid arthritis. PLoS Med 2007; 4:e278.

20. Plant D, Thomson W, Lunt M, et al. The role of rheumatoid arthritis genetic susceptibility markers in the prediction of erosive disease in patients with early inflammatory polyarthritis: Result from the Norfolk Arthritis Register. In Press. 2010. Rheumatology.
21. Barton A, Bowes J, Eyre S, et al. A functional haplotype of the PADI4 gene associated with rheumatoid arthritis in a Japanese population is not associated in a United Kingdom population. Arthritis Rheum 2004;50:1117-21.

22. Gandjbakhch F, Fajardy I, Ferré B, et al. A functional haplotype of PADI4 gene in rheumatoid arthritis: positive correlation in a French population. $\mathrm{J}$ Rheumatol 2009;36:881-6.

23. Harney SM, Meisel C, Sims AM, et al. Genetic and genomic studies of PADI4 in rheumatoid arthritis. Rheumatology (Oxford) 2005;44:869-72.

24. Hoppe B, Häupl T, Egerer K, et al. Influence of peptidylarginine deiminase type 4 genotype and shared epitope on clinical characteristics and autoantibody profile of rheumatoid arthritis. Ann Rheum Dis 2009;68:898-903.

25. Martinez A, Valdivia A, Pascual-Salcedo D, et al. PADI4 polymorphisms are not associated with rheumatoid arthritis in the Spanish population. Rheumatology (Oxford) 2005;44:1263-6.

26. Plenge RM, Padyukov L, Remmers EF, et al. Replication of putative candidate-gene associations with rheumatoid arthritis in $>4,000$ samples from North America and Sweden: association of susceptibility with PTPN22, CTLA4, and PADI4. Am J Hum Genet 2005;77:1044-60.

27. Suzuki A, Yamada R, Chang X, et al. Functional haplotypes of PADI4, encoding citrullinating enzyme peptidylarginine deiminase 4, are associated with rheumatoid arthritis. Nat Genet 2003;34:395-402.

28. Yasuda H, Shima N, Nakagawa N, et al. Osteoclast differentiation factor is a ligand for osteoprotegerin/osteoclastogenesis-inhibitory factor and is identical to TRANCE/RANKL. Proc Natl Acad Sci USA 1998;95:3597-602.

29. Shigeyama Y, Pap T, Kunzler P, et al. Expression of osteoclast differentiation factor in rheumatoid arthritis. Arthritis Rheum 2000;43:2523-30.

30. Geusens PP, Landewé RB, Garnero P, et al. The ratio of circulating osteoprotegerin to RANKL in early rheumatoid arthritis predicts later joint destruction. Arthritis Rheum 2006;54:1772-7.

31. van Tuyl LHD, Voskuyl A, Boers M, et al. Baseline RANKL:OPG Ratio and Markers of Bone and Cartilage Degradation Predict Annual Radiological Progression Over 11 Years in Rheumatoid Arthritis [abstract]. 2007;60:351. Arthritis rheum.

32. Skoumal M, Haberhauer G, Kolarz G, et al. The imbalance between osteoprotegerin and cathepsin $\mathrm{K}$ in the serum of patients with longstanding rheumatoid arthritis. Rheumatol Int 2008;28:637-41. 
33. Syversen SW, Goll GL, van der Heijde D, et al. Cartilage and bone biomarkers in rheumatoid arthritis: prediction of 10year radiographic progression. $\mathrm{J}$ Rheumatol 2009;36:266-72.

34. Garnero P, Landewé R, Boers M, et al. Association of baseline levels of markers of bone and cartilage degradation with long-term progression of joint damage in patients with early rheumatoid arthritis: the COBRA study. Arthritis Rheum 2002;46:2847-56.

35. Mânsson B, Gülfe A, Geborek P, et al. Release of cartilage and bone macromolecules into synovial fluid: differences between psoriatic arthritis and rheumatoid arthritis. Ann Rheum Dis 2001;60:2731.

36. Larsson E, Müssener A, Heinegârd D, et al. Increased serum levels of cartilage oligomeric matrix protein and bone sialoprotein in rats with collagen arthritis. $\mathrm{Br}$ J Rheumatol 1997;36:1258-61.

37. Mânsson B, Geborek P, Saxne T. Cartilage and bone macromolecules in knee joint synovial fluid in rheumatoid arthritis: relation to development of knee or hip joint destruction. Ann Rheum Dis 1997;56:91-6.

38. Nakamura RM. Progress in the use of biochemical and biological markers for evaluation of rheumatoid arthritis. J Clin Lab Anal 2000;14:305-13.

39. Meier C, Meinhardt U, Greenfield JR, et al. Serum cathepsin K concentrations reflect osteoclastic activity in women with postmenopausal osteoporosis and patients with Paget's disease. Clin Lab 2006;52:1-10.

40. van den Broek T, Tesser JR, Albani S. The evolution of biomarkers in rheumatoid arthritis: from clinical research to clinical care. Expert Opin Biol Ther 2008;8:177385.

41. Vis M, Havaardsholm EA, Haugeberg G, et al. Evaluation of bone mineral density, bone metabolism, osteoprotegerin and receptor activator of the NFkappaB ligand serum levels during treatment with infliximab in patients with rheumatoid arthritis. Ann Rheum Dis 2006;65:1495-9.

42. Cloos PA, Christgau S. Characterization of aged osteocalcin fragments derived from bone resorption. Clin Lab 2004;50:585-98.

43. Skoumal M, Haberhauer G, Feyertag J, et al. Serum levels of cartilage oligomeric matrix protein are elevated in rheumatoid arthritis, but not in inflammatory rheumatic diseases such as psoriatic arthritis, reactive arthritis, Raynaud's syndrome, scleroderma, systemic lupus erythematosus, vasculitis and Sjogren's syndrome. Arthritis Res Ther 2004;6:73-
4. [Abstract] 44. Lindqvist E, Eberhardt K, Bendtzen K, et al. Prognostic laboratory markers of joint damage in rheumatoid arthritis. Ann Rheum Dis 2005;64:196201.

45. Larsson E, Erlandsson Harris H, Lorentzen JC, et al. Serum concentrations of cartilage oligomeric matrix protein, fibrinogen and hyaluronan distinguish inflammation and cartilage destruction in experimental arthritis in rats. Rheumatology (Oxford) 2002;41:9961000.

46. Mânsson B, Carey D, Alini M, et al. Cartilage and bone metabolism in rheumatoid arthritis. Differences between rapid and slow progression of disease identified by serum markers of cartilage metabolism. J Clin Invest 1995;95:1071-7.

47. Fex E, Eberhardt K, Saxne T. Tissuederived macromolecules and markers of inflammation in serum in early rheumatoid arthritis: relationship to development of joint destruction in hands and feet. $\mathrm{Br}$ J Rheumatol 1997;36:1161-5.

48. Roux-Lombard P, Eberhardt K, Saxne T, et al. Cytokines, metalloproteinases, their inhibitors and cartilage oligomeric matrix protein: relationship to radiological progression and inflammation in early rheumatoid arthritis. A prospective 5-year study. Rheumatology (Oxford) 2001; 40:544-51.

49. Saxne T, Heinegârd D. Cartilage oligomeric matrix protein: a novel marker of cartilage turnover detectable in synovial fluid and blood. Br J Rheumatol 1992;31:583-91.

50. Poole AR, Ionescu M, Swan A, Dieppe PA. Changes in cartilage metabolism in arthritis are reflected by altered serum and synovial fluid levels of the cartilage proteoglycan aggrecan. Implications for pathogenesis. J Clin Invest 1994;94:25-33.

51. Charni-Ben Tabassi N, Garnero P. Monitoring cartilage turnover. Curr Rheumatol Rep 2007;9:16-24.

52. Fosang AJ, Stanton H, Little CB, Atley LM. Neoepitopes as biomarkers of cartilage catabolism. Inflamm Res 2003;52:277-82.

53. Larsson S, Lohmander LS, Struglics A. Synovial fluid level of aggrecan ARGS fragments is a more sensitive marker of joint disease than glycosaminoglycan or aggrecan levels: a cross-sectional study. Arthritis Res Ther 2009;11:R92.

54. Rousseau JC, Sumer EU, Hein G, et al. Patients with rheumatoid arthritis have an altered circulatory aggrecan profile. BMC Musculoskelet Disord 2008;9:74.

55. Garnero P, Gineyts E, Christgau S, et al. Association of baseline levels of urinary glucosyl-galactosyl-pyridinoline and type
II collagen C-telopeptide with progression of joint destruction in patients with early rheumatoid arthritis. Arthritis Rheum 2002;46:21-30.

56. Landewé RB, Geusens P, van der Heijde DM, et al. Arthritis instantaneously causes collagen type I and type II degradation in patients with early rheumatoid arthritis: a longitudinal analysis. Ann Rheum Dis 2006;65:40-4.

57. Oestergaard S, Chouinard L, Doyle N, et al. The utility of measuring C-terminal telopeptides of collagen type II (CTX-II) in serum and synovial fluid samples for estimation of articular cartilage status in experimental models of destructive joint diseases. 0steoarthritis Cartilage 2006;14:670-9.

58. Marotte H, Gineyts E, Miossec P, Delmas PD. Effects of infliximab therapy on biological markers of synovium activity and cartilage breakdown in patients with rheumatoid arthritis. Ann Rheum Dis 2009;68:1197-200.

59. Hashimoto J, Garnero P, van der Heijde D, et al. A combination of biochemical markers of cartilage and bone turnover, radiographic damage and body mass index to predict the progression of joint destruction in patients with rheumatoid arthritis treated with disease-modifying anti-rheumatic drugs. Mod Rheumatol 2009;19:27382.

60. Okada Y, Gonoji Y, Nakanishi I, et al. Immunohistochemical demonstration of collagenase and tissue inhibitor of metalloproteinases (TIMP) in synovial lining cells of rheumatoid synovium. Virchows Arch B Cell Pathol Incl Mol Pathol 1990; 59:305-12.

61. Okada Y, Takeuchi N, Tomita K, et al. Immunolocalization of matrix metalloproteinase 3 (stromelysin) in rheumatoid synovioblasts (B cells): correlation with rheumatoid arthritis. Ann Rheum Dis 1989;48:645-53.

62. Ahrens D, Koch AE, Pope RM, et al. Expression of matrix metalloproteinase 9 (96-kd gelatinase B) in human rheumatoid arthritis. Arthritis Rheum 1996;39:1576-87.

63. Miller MC, Manning HB, Jain A, et al. Membrane type 1 matrix metalloproteinase is a crucial promoter of synovial invasion in human rheumatoid arthritis. Arthritis Rheum 2009;60:686-97.

64. Yoshihara Y, Nakamura H, Obata K, et al. Matrix metalloproteinases and tissue inhibitors of metalloproteinases in synovial fluids from patients with rheumatoid arthritis or osteoarthritis. Ann Rheum Dis 2000;59:455-61.[Abstract] 65. Yamanaka H, Matsuda Y, Tanaka M, et al. Serum matrix metalloproteinase 3 as a 
predictor of the degree of joint destruction during the six months after measurement, in patients with early rheumatoid arthritis. Arthritis Rheum 2000;43:852-8.

66. Young-Min S, Cawston T, Marshall N, et al. Biomarkers predict radiographic progression in early rheumatoid arthritis and perform well compared with traditional markers. Arthritis Rheum 2007;56:3236-47.

67. Chang YH, Lin IL, Tsay GJ, et al. Elevated circulatory MMP-2 and MMP-9 levels and activities in patients with rheumatoid arthritis and systemic lupus erythematosus. Clin Biochem 2008;41:955-9.

68. Rooney T, Roux-Lombard P, Veale DJ, et al. Synovial tissue and serum biomarkers of disease activity, therapeutic response and radiographic progression: analysis of a proof-of-concept randomised clinical trial of cytokine blockade. Ann Rheum Dis 2010;69:706-14.

69. Fraser A, Fearon U, Billinghurst RC, et al. Turnover of type II collagen and aggrecan in cartilage matrix at the onset of inflammatory arthritis in humans: relationship to mediators of systemic and local inflammation. Arthritis Rheum 2003;48:3085-95.

70. Verstappen SM, Poole AR, Ionescu M, et al. Radiographic joint damage in rheumatoid arthritis is associated with differences in cartilage turnover and can be predicted by serum biomarkers: an evaluation from 1 to 4 years after diagnosis. Arthritis Res Ther 2006;8:R31.

71. Gineyts E, Garnero P, Delmas PD. Urinary excretion of glucosyl-galactosyl pyridinoline: a specific biochemical marker of synovium degradation. Rheumatology (Oxford) 2001;40:315-23.

72. Emlen W, Niebur J, Flanders G, et al. Measurement of serum hyaluronic acid in patients with rheumatoid arthritis: correlation with disease activity. J Rheumatol 1996;23:974-8.

73. Chubinskaya S, Frank BS, Michalska M, et al. Osteogenic protein 1 in synovial fluid from patients with rheumatoid arthritis or osteoarthritis: relationship with disease and levels of hyaluronan and antigenic keratan sulfate. Arthritis Res Ther 2006;8:R73.

74. Chen PP, Fong S, Carson DA. Rheumatoid factor. Rheum Dis Clin North Am 1987;13:545-68.

75. Arnett FC, Edworthy SM, Bloch DA, et al. The American Rheumatism Association 1987 revised criteria for the classification of rheumatoid arthritis. Arthritis Rheum 1988;31:315-24.

76. Aho K, Palusuo T, Kurki P. Marker antibodies of rheumatoid arthritis: diagnostic and pathogenetic implications. Semin Arthritis Rheum 1994;23:379-87.
77. Lane SK, Gravel JW Jr. Clinical utility of common serum rheumatologic tests. Am Fam Physician 2002;65:1073-80.

78. Rantapää-Dahlqvist S. What happens before the onset of rheumatoid arthritis? Curr Opin Rheumatol 2009;21:272-8.

79. Emery P. The Dunlop-Dottridge Lecture: prognosis in inflammatory arthritis: the value of HLA genotyping and the oncological analogy. J Rheumatol 1997;24:143642.

80. Goronzy JJ, Matteson EL, Fulbright JW, et al. Prognostic markers of radiographic progression in early rheumatoid arthritis. Arthritis Rheum 2004;50:43-54.

81. Barland P, Lipstein E. Selection and use of laboratory tests in the rheumatic diseases. Am J Med 1996;100:16S-23S.

82. Valdimarsson H, Jónsson T. Predictive value of rheumatoid factor isotypes for radiological progression in patients with rheumatoid arthritis. Scand J Rheumatol 1996;25:189-90.

83. Tedesco A, D'Agostino D, Soriente I, et al. A new strategy for the early diagnosis of rheumatoid arthritis: a combined approach. Autoimmun Rev 2009;8:233-7.

84. Rantapää-Dahlqvist S, de Jong BA, Berglin E, et al. Antibodies against cyclic citrullinated peptide and IgA rheumatoid factor predict the development of rheumatoid arthritis. Arthritis Rheum 2003;48:2741-9.

85. Nielen MM, van Schaardenburg D, Reesink HW, et al. Specific autoantibodies precede the symptoms of rheumatoid arthritis: a study of serial measurements in blood donors. Arthritis Rheum 2004;50:380-6.

86. Wild N, Karl J, Grunert VP, et al. Diagnosis of rheumatoid arthritis: multivariate analysis of biomarkers. Biomarkers 2008;13:88-105.

87. Emery P, McInnes IB, van Vollenhoven R, Kraan MC. Clinical identification and treatment of a rapidly progressing disease state in patients with rheumatoid arthritis. Rheumatology (0xford) 2008;47:392-8.

88. Nell VP, Machold KP, Stamm TA, et al. Autoantibody profiling as early diagnostic and prognostic tool for rheumatoid arthritis. Ann Rheum Dis 2005;64:1731-6.

89. Syversen SW, Gaarder PI, Goll GL, et al. High anti-cyclic citrullinated peptide levels and an algorithm of four variables predict radiographic progression in patients with rheumatoid arthritis: results from a 10-year longitudinal study. Ann Rheum Dis 2008;67:212-7.

90. Rojas-Serrano J, Burgos-Vargas R, Pérez LL, et al. Very recent onset arthritis: the value of initial rheumatologist evaluation and anti-cyclic citrullinated peptide anti- bodies in the diagnosis of rheumatoid arthritis. Clin Rheumatol 2009;28:1135-9.

91. Avouac J, Gossec L, Dougados M. Diagnostic and predictive value of anticyclic citrullinated protein antibodies in rheumatoid arthritis: a systematic literature review. Ann Rheum Dis 2006;65:84551.

92. Combe B, Landewe R, Lukas $\mathrm{C}$, et al. EULAR recommendations for the management of early arthritis: report of a task force of the European Standing Committee for International Clinical Studies Including Therapeutics (ESCISIT). Ann Rheum Dis 2007;66:3445.

93. Liao KP, Batra KL, Chibnik L, et al. Anticyclic citrullinated peptide revised criteria for the classification of rheumatoid arthritis. Ann Rheum Dis 2008;67:155761.

94. de Vries RR, Huizinga TW, Toes RE. Redefining the HLA and RA association: to be or not to be anti-CCP positive. $\mathrm{J}$ Autoimmun 2005;25:21-5.

95. Rojas-Villarraga A, Diaz FJ, Calvo-Páramo $\mathrm{E}$, et al. Familial disease, the HLA-DRB1 shared epitope and anti-CCP antibodies influence time at appearance of substantial joint damage in rheumatoid arthritis. J Autoimmun 2009;32:64-9.

96. Szodoray P, Szabó Z, Kapitány A, et al. Anti-citrullinated protein/peptide autoantibodies in association with genetic and environmental factors as indicators of disease outcome in rheumatoid arthritis. Autoimmun Rev 2010;9:140-3.

97. van Venrooij WJ, van Beers JJ, Pruijn GJ. Anti-CCP Antibody, a Marker for the Early Detection of Rheumatoid Arthritis. Ann NY Acad Sci 2008;1143:268-85.

98. Vincent C, Serre G, Lapeyre F, et al. High diagnostic value in rheumatoid arthritis of antibodies to the stratum corneum of rat oesophagus epithelium, so-called 'antikeratin antibodies'. Ann Rheum Dis 1989;48:712-22.

99. Kurki P, Aho K, Palosuo T, Heliövaara M. Immunopathology of rheumatoid arthritis. Antikeratin antibodies precede the clinical disease. Arthritis Rheum 1992;35:914-7.

100. Paimela L, Gripenberg M, Kurki P, Leirisalo-Repo M. Antikeratin antibodies: diagnostic and prognostic markers for early rheumatoid arthritis. Ann Rheum Dis 1992;51:743-6.

101. Westgeest AA, Boerbooms AM, Jongmans $\mathrm{M}$, et al. Antiperinuclear factor: indicator of more severe disease in seronegative rheumatoid arthritis. J Rheumatol 1987;14:893-7.

102. Vencovský J, Machácek S, Sedová L, et al. Autoantibodies can be prognostic mark- 
ers of an erosive disease in early rheumatoid arthritis. Ann Rheum Dis 2003;62:427-30.

103. Saraux A, Berthelot JM, Devauchelle V, et al. Value of antibodies to citrulline-containing peptides for diagnosing early rheumatoid arthritis. J Rheumatol 2003;30:2535-9.

104. Vossenaar ER, Després N, Lapointe E, et al. Rheumatoid arthritis specific anti-Sa antibodies target citrullinated vimentin. Arthritis Res Ther 2004;6:R142-50.

105. Bang H, Egerer K, Gauliard A, et al. Mutation and citrullination modifies vimentin to a novel autoantigen for rheumatoid arthritis. Arthritis Rheum 2007;56:2503-11.

106. Innala L, Kokkonen H, Eriksson C, et al. Antibodies against mutated citrullinated vimentin are a better predictor of disease activity at 24 months in early rheumatoid arthritis than antibodies against cyclic citrullinated peptides. J Rheumatol 2008;35:1002-8.

107.Ursum J, Nielen MM, van Schaardenburg D, et al. Antibodies to mutated citrullinated vimentin and disease activity score in early arthritis: a cohort study. Arthritis Res Ther 2008;10:R12.

108. Luime JJ, Colin EM, Hazes JMW, Lubberts E. Does anti-MCV have additional value as serological marker in the diagnostic and prognostic work-up of patients with rheumatoid arthritis? A systematic review. Ann Rheum Dis 2010;69:33744. [Abstract] 109. van der Linden MP, van der Woude D, IoanFacsinay A, et al. Value of anti-modified citrullinated vimentin and third-generation anti-cyclic citrullinated peptide compared with second-generation anti-cyclic citrullinated peptide and rheumatoid factor in predicting disease outcome in undifferentiated arthritis and rheumatoid arthritis. Arthritis Rheum 2009;60:223241.

110.Wagner E, Skoumal M, Bayer PM, Klaushofer K. Antibody against mutated citrullinated vimentin: a new sensitive marker in the diagnosis of rheumatoid arthritis. Rheumatol Int 2009;29:1315-21.

111. Bläss S, Specker C, Lakomek HJ, et al. Novel $68 \mathrm{kDa}$ autoantigen detected by rheumatoid arthritis specific antibodies. Ann Rheum Dis 1995;54:355-60.

112. Blass S, Union A, Raymackers J, et al. The stress protein $\mathrm{BiP}$ is overexpressed and is a major B and T cell target in rheumatoid arthritis. Arthritis Rheum 2001;44:761-71.

113. Corrigall VM, Bodman-Smith MD, Fife MS, et al. The human endoplasmic reticulum molecular chaperone $\mathrm{BiP}$ is an autoantigen for rheumatoid arthritis and prevents the induction of experimental arthritis. J Immunol 2001;166:1492-8.

114. Bodman-Smith MD, Corrigall VM, Berglin E, et al. Antibody response to the human stress protein $\mathrm{BiP}$ in rheumatoid arthritis. Rheumatology (Oxford) 2004;43:12837.

115. Morel J, Combe B. How to predict prognosis in early rheumatoid arthritis. Best Pract Res Clin Rheumatol 2005;19:137-46.

116.van Leeuwen MA, van Rijswijk MH, van der Heijde DM, T et al. The acute-phase response in relation to radiographic progression in early rheumatoid arthritis: a prospective study during the first three years of the disease. $\mathrm{Br} \mathrm{J}$ Rheumatol 1993; 32:9-13.

117. Talstad I, Scheie P, Dalen H, Röli J. Influence of plasma proteins on erythrocyte morphology and sedimentation. Scand J Haematol 1983;31:478-84.

118. Vastesaeger N, Xu S, Aletaha D, et al. A pilot risk model for the prediction of rapid radiographic progression in rheumatoid arthritis. Rheumatology (Oxford) 2009;48:1114-21.

119. Plant MJ, Williams AL, O'Sullivan MM, et al. Relationship between time-integrated C-reactive protein levels and radiologic progression in patients with rheumatoid arthritis. Arthritis Rheum 2000;43:1473-7.

120. Jansen LM, van der Horst-Bruinsma IE, van Schaardenburg D, et al. Predictors of radiographic joint damage in patients with early rheumatoid arthritis. Ann Rheum Dis 2001;60:924-7.

121. Aletaha D, Nell VP, Stamm T, et al. Acute phase reactants add little to composite disease activity indices for rheumatoid arthritis: validation of a clinical activity score. Arthritis Res Ther 2005;7:R796R806.

122. Bukhari M, Lunt M, Harrison BJ, et al. Rheumatoid factor is the major predictor of increasing severity of radiographic erosions in rheumatoid arthritis: results from the Norfolk Arthritis Register Study, a large inception cohort. Arthritis Rheum 2002;46:906-12.

123. Brun JG, Jonsson R, Haga HJ. Measurement of plasma calprotectin as an indicator of arthritis and disease activity in patients with inflammatory rheumatic diseases. J Rheumatol 1994;21:7338.

124. Berntzen HB, Olmez U, Fagerhol MK, Munthe E. The leukocyte protein L1 in plasma and synovial fluid from patients with rheumatoid arthritis and osteoarthritis. Scand J Rheumatol 1991;20:74-82.

125. Hammer HB, Odegard S, Fagerhol MK, et al. Calprotectin (a major leucocyte protein) is strongly and independently correlated with joint inflammation and damage in rheumatoid arthritis. Ann Rheum Dis 2007;66:1093-7.

126. Hammer HB, Odegard S, Syversen SW, Landewe R, van der HD, Uhlig $\mathrm{T}$ et al. Calprotectin (a major S100 leukocyte protein) predicts 10 -year radiographic progression in patients with rheumatoid arthritis. Ann Rheum Dis 2010;69:1504.[Abstract] 127. Kumon Y, Loose LD, Birbara CA, Sipe JD. Rheumatoid arthritis exhibits reduced acute phase and enhanced constitutive serum amyloid A protein in synovial fluid relative to serum. A comparison with $\mathrm{C}$ reactive protein. J Rheumatol 1997;24:149.

128. Kokubun M, Imafuku Y, Okada M, et al. Serum amyloid A (SAA) concentration varies among rheumatoid arthritis patients estimated by SAACRP ratio. Clin Chim Acta 2005;360:97-102.

129. Migita K, Kawabe Y, Tominaga M, et al. Serum amyloid A protein induces production of matrix metalloproteinases by human synovial fibroblasts. Lab Invest 1998;78:535-9.

130. Klimiuk PA, Sierakowski S, Latosiewicz R, et al. Soluble adhesion molecules (ICAM1, VCAM-1, and E-selectin) and vascular endothelial growth factor (VEGF) in patients with distinct variants of rheumatoid synovitis. Ann Rheum Dis 2002;61:804-9.

131. Navarro-Hernández RE, Oregón-Romero E, Rangel-Villalobos $\mathrm{H}$, et al. sE-Selectin expression and A561C polymorphism in relation to rheumatoid arthritis clinical activity. J Rheumatol 2006;33:1968-72.

132. Jikimoto T, Nishikubo Y, Koshiba M, et al. Thioredoxin as a biomarker for oxidative stress in patients with rheumatoid arthritis. Mol Immunol 2002;38:765-72.

133. Maurice MM, Nakamura H, Gringhuis S, et al. Expression of the thioredoxinthioredoxin reductase system in the inflamed joints of patients with rheumatoid arthritis. Arthritis Rheum 1999;42:2430-9.

134. Blann AD, Herrick A, Jayson MI. Altered levels of soluble adhesion molecules in rheumatoid arthritis, vasculitis and systemic sclerosis. $\mathrm{Br} \mathrm{J}$ Rheumatol 1995;34:814-9.

135. Mason JC, Kapahi P, Haskard DO. Detection of increased levels of circulating intercellular adhesion molecule 1 in some patients with rheumatoid arthritis but not in patients with systemic lupus erythematosus. Lack of correlation with levels of circulating vascular cell adhesion molecule 1. Arthritis Rheum 1993;36:519-27.

136. Ugur M, Yildirim K, Kiziltunc A, et al. Correlation between soluble intercellular 
adhesion molecule 1 level and extracellular superoxide dismutase activity in rheumatoid arthritis: a possible association with disease activity. Scand J Rheumatol 2004;33:239-43.

137. Klimiuk PA, Fiedorczyk M, Sierakowski S, Chwiecko J. Soluble cell adhesion molecules (sICAM-1, sVCAM-1, and sEselectin) in patients with early rheumatoid arthritis. Scand J Rheumatol 2007;36:345-50.

138. Firestein GS. Evolving concepts of rheumatoid arthritis. Nature 2003;423: $356-61$.

139. Redlich K, Hayer S, Ricci R, et al. Osteoclasts are essential for TNF-alphamediated joint destruction. J Clin Invest 2002;110:1419-27.

140. Feldmann M, Brennan FM, Maini RN. Role of cytokines in rheumatoid arthritis. Annu Rev Immunol 1996;14:397-440.

141. Kotake S, Udagawa N, Takahashi N, et al. IL-17 in synovial fluids from patients with rheumatoid arthritis is a potent stimulator of osteoclastogenesis. J Clin Invest 1999;103:1345-52.

142. Cope AP, Aderka D, Doherty M, et al. Increased levels of soluble tumor necrosis factor receptors in the sera and synovial fluid of patients with rheumatic diseases. Arthritis Rheum 1992;35:1160-9.

143. Steiner G, Studnicka-Benke A, Witzmann G, et al. Soluble receptors for tumor necrosis factor and interleukin-2 in serum and synovial fluid of patients with rheumatoid arthritis, reactive arthritis and osteoarthritis. J Rheumatol 1995; 22:406-12.

144. Dayer JM, Choy E. Therapeutic targets in rheumatoid arthritis: the interleukin- 6 receptor. Rheumatology (Oxford) 2010;49: 15-24.

145. Eastgate JA, Symons JA, Wood NC. Correlation of plasma interleukin 1 levels with disease activity in rheumatoid arthritis. Lancet 1988;2:706-9.

146. van Leeuwen MA, Westra J, Limburg PC, et al. Clinical significance of interleukin6 measurement in early rheumatoid arthritis: relation with laboratory and clinical variables and radiological progression in a three year prospective study. Ann Rheum Dis 1995;54:674-7.

147. Knudsen LS, Christensen IJ, Lottenburger T, et al. Pre-analytical and biological variability in circulating interleukin 6 in healthy subjects and patients with rheumatoid arthritis. Biomarkers 2008;13:59-78.

148. Karlson EW, Chibnik LB, Tworoger SS, et al. Biomarkers of inflammation and development of rheumatoid arthritis in women from two prospective cohort studies. Arthritis Rheum 2009;60:641-52.

149. Jorgensen KT, Wiik A, Pedersen M, et al. Cytokines, autoantibodies and viral antibodies in premorbid and postdiagnostic sera from patients with rheumatoid arthritis: case-control study nested in a cohort of Norwegian blood donors. Ann Rheum Dis 2008;67:860-6.

150. Raza K, Falciani F, Curnow SJ, Ross EJ, et al. Early rheumatoid arthritis is characterized by a distinct and transient synovial fluid cytokine profile of $\mathrm{T}$ cell and stromal cell origin. Arthritis Res Ther 2005;7:R784-95.

151. Koenders MI, Joosten LA, van den Berg WB. Potential new targets in arthritis therapy: interleukin (IL)-17 and its relation to tumour necrosis factor and IL-1 in experimental arthritis. Ann Rheum Dis 2006;65 Suppl 3:iii29-33.

152. Miossec P, Korn T, Kuchroo VK. Interleukin-17 and type 17 helper T cells. N Engl J Med 2009;361:888-98.

153. Kirkham BW, Lassere MN, Edmonds JP, et al. Synovial membrane cytokine expression is predictive of joint damage progression in rheumatoid arthritis: a two-year prospective study (the DAMAGE study cohort). Arthritis Rheum 2006;54:112231.

154. Rho YH, Solus J, Sokka T, et al. Adipocytokines are associated with radiographic joint damage in rheumatoid arthritis. Arthritis Rheum 2009;60:1906-14.

155. Iwamoto T, Okamoto H, Toyama Y, Momohara S. Molecular aspects of rheumatoid arthritis: chemokines in the joints of patients. FEBS J 2008;275:444855.

156. Rioja I, Hughes FJ, Sharp CH, et al. Potential novel biomarkers of disease activity in rheumatoid arthritis patients: CXCL13, CCL23, transforming growth factor alpha, tumor necrosis factor receptor superfamily member 9 , and macrophage colony-stimulating factor. Arthritis Rheum 2008;58:2257-67.

157. Cope AP. T cells in rheumatoid arthritis. Arthritis Res Ther 2008;10 Suppl 1:S1.

158. Sakaguchi S. Naturally arising CD4+ regulatory $t$ cells for immunologic self-toler- ance and negative control of immune responses. Annu Rev Immunol 2004; 22:531-62.

159. Faria AM, Weiner HL. Oral tolerance. Immunol Rev 2005;206:232-59.

160. Ehrenstein MR, Evans JG, Singh A, et al. Compromised function of regulatory $\mathrm{T}$ cells in rheumatoid arthritis and reversal by anti-TNFalpha therapy. J Exp Med 2004;200:277-85.

161.Londei M. Role of regulatory T cells in experimental arthritis and implications for clinical use. Arthritis Res Ther 2005; 7:118-20.

162.Cao D, van Vollenhoven R, Klareskog L, Trollmo C, Malmstrom V. CD25bright CD4+ regulatory $\mathrm{T}$ cells are enriched in inflamed joints of patients with chronic rheumatic disease. Arthritis Res Ther 2004;6:R335-46.

163. van Amelsfort JM, Jacobs KM, Bijlsma JW, et al. $\mathrm{CD} 4(+) \mathrm{CD} 25(+)$ regulatory $\mathrm{T}$ cells in rheumatoid arthritis: differences in the presence, phenotype, and function between peripheral blood and synovial fluid. Arthritis Rheum 2004;50:2775-85.

164.van Amelsfort JM, van Roon JA, Noordegraaf $M$, et al. Proinflammatory mediator-induced reversal of $\mathrm{CD} 4+$, CD25+ regulatory $\mathrm{T}$ cell-mediated suppression in rheumatoid arthritis. Arthritis Rheum 2007;56:732-42.

165. Lawson CA, Brown AK, Bejarano V, et al. Early rheumatoid arthritis is associated with a deficit in the CD4+CD25high regulatory $\mathrm{T}$ cell population in peripheral blood. Rheumatology (Oxford) 2006;45:1210-7.

166. Liu MF, Wang CR, Fung LL, et al. The presence of cytokine-suppressive CD4+CD25+ $\mathrm{T}$ cells in the peripheral blood and synovial fluid of patients with rheumatoid arthritis. Scand J Immunol 2005;62:312-7.

167. Möttönen M, Heikkinen J, Mustonen L, et al. CD4+ CD25+ T cells with the phenotypic and functional characteristics of regulatory $\mathrm{T}$ cells are enriched in the synovial fluid of patients with rheumatoid arthritis. Clin Exp Immunol 2005;140:360-7.

167. Mottonen M, Heikkinen J, Mustonen L, et al. CD4+ CD25+ T cells with the phenotypic and functional characteristics of regulatory $T$ cells are enriched in the synovial fluid of patients with rheumatoid arthritis. Clin Exp Immunol 2005;140:3607. 